\title{
Initiation of the Adventure-A Study on Young Jules’ Psychological Alienation in them
}

\author{
WANG Yu-qing \\ Heze University, Heze, China
}

\begin{abstract}
Joyce Carol Oates (1938- ) is one of the most prolific and versatile contemporary writers in America. As a realistic novel and one of the masterpieces of the author, them reflects the psychological progress of the people of the lower class in American society from the great depression of the 1930s to the turbulence of the 1960s. In their pursuit of material life as well as spiritual comfort, they undergo many hardships and confront with the multiple pressures from family, society and even themselves. This paper lays emphasis on two stages in which young Jules Wendall quests for personal longings. The first stage is Jules's early years in the rural area as a little boy. During this period, he is searching for freedom by running away from home more than once. He longs to reach somewhere distant. Yet, he is left confused while staying with his family with no way out. The runaway action is his first try for a better life. The second stage is his teenage years during which he experiences a move to the urban city and suffers from great dilemma due to the big contrast between the chaotic urban life and the peaceful rural life. Disappointed with his dysfunctional family, he sees himself as a self-made man and turns to himself for a successful future.
\end{abstract}

Keywords: initiation, alienation, rebellion, psychoanalysis

\section{Introduction}

With the change of the style, Joyce Carol Oates (1938- ) concentrates on the spiritual, intellectual, and psychological malaise of modern American society in her fictive world, exposing the darker aspects of the human situation. Most critics maintain that Oates vividly represents the underlying tensions of modern American society in her explosive tales and, at the same time, stretches the boundaries of the conventional short story. Oates is excellent at conveying psychological state of an individual experience in complete detail, and relating the intense private experiences of her characters to the larger realities of American life. As Johnson (2006) put it, “Oates's fiction portrays America as a seething, vibrant 'wonderland' in which individual lives are frequently subject to disorder, dislocation, and extremely psychological turmoil” (p. 8).

Oates' works have their own unique characteristics. Firstly her emphasis on the spiritual and psychological dimensions of human life is of significance that distinguishes her from the traditional naturalistic writers.

Oates differs from the naturalists on philosophic grounds... Perhaps the most radical departure of her fiction from that of the naturalists is in her depiction of the will... while in Oates's fiction the destructive power of the will becomes one of the author's primary targets. (Friedman, 1980, p. 57)

WANG Yu-qing, lecturer, Foreign Language Department, Heze University. 
Oates, as a master hand of psychological realism, depicts her protagonist's psychological confusion upon the broken realistic world. Secondly, Oates stresses the concept of human struggle in her fiction. Oates's uniqueness exists in that she successfully.

She has published myriad novels, poetries, and plays, as well as books and articles of criticism. In these works, Oates focuses on what she views as the spiritual, sexual, and intellectual decline of modern American society. Employing a dense, elliptical prose style, she depicts such cruel and macabre actions as rape, incest, murder, child abuse, and suicide to delineate the forces of evil with which individuals must contend.

As an individual, people have to face the problem of growing up on one hand, and locate him properly in the society on the other hand. However, it is more or less difficult to realize his self-location, because the role one plays is very much influenced by the environment one lives in. In them, Oates creates a violent world in which, as a young adolescent, Jules stubbornly cherishes romantic dreams and strives to realize it. The romantic dreams display his sense of self-importance as a way to identify himself. In his boyhood, while staying with his family in the countryside, he seeks for some childish freedom by means of running away from home. After moving to Detroit, he develops many fantasies about the future life and pursues the union of love and wealth as a romantic adventure. Unfortunately, the massive difference between the reality and fantasy disillusions him so much that he suffers from great dilemma while lost in his ideal. After many frustrations, he finally gives up and joins in the alienated community.

\section{Puzzlement in the Childhood}

First and foremost, Oates takes the protagonist's boyhood into consideration in the whole course of an individual's growth since it has been a part of the protagonist's protest and alienation. In the rural countryside, Jules feels alone and seeks his ideal place by running away which can be treated as a journey of self-knowledge that can enable him to survive spiritually. Moving from the village to the city, he feels excluded by the urban environment since he lives but is not viewed as participants. Both in the village and in the city, the marginalized identity thus achieved later contributes to Jules's alienation.

\section{Runaways From the Rural Area}

In the countryside, Jules grows up feeling excluded and alone. The first of several symbolic markers of Jules's separation and his brokenness come when he firstly attempts to run away from home. Being incompatible with the stagnant environment, Jules dreams of escaping to some distant place. He is not guilty or frightened by escaping from home. On the contrary, when he whispers his name to the woman, he feels nothing but "ashamed and perplexed" When he is sent back home, and at the sight of the house, he considers it as "the high, gaunt, ugly Wendall house that was an eyesore even among the eyesores of the Huron Road... He dreamed about running away again, back to that farmhouse or to another like it” (Oates, 1969, p. 73). Of course, this is the first frustration of his ideal attempts, but it has a tremendous influence on Jules's attitude towards the struggle for freedom in a brutal environment. In one of the author's evaluation, Oates (1969) stated:

Of the effort the spirit makes, this is the subject of Jules's story; of its effort to achieve freedom, its breaking out into beauty, in patches of beauty perhaps anyway, and of Jules as an American youth-these are some of the struggles he would have thought worth recording. (p. 274) 
Jules's later actions prove that resistance has been rooted deeply in his mind ever since his very boyhood. His pursuit of freedom and individuality has been formed in an embryo in this period and never cease in the rest of his life. The reason lies in the fact that he is born to be a romantic hero, and to him freedom is most important. When he is about ten, he is accustomed to running away from home every few months, curious about the city and bitter about home. He always ends up in the Children’s Shelter—a place worse than home.

After repeated flights from his family, he ultimately has to face the reality. With no guide, no instruction, nowhere Jules can head for in the world. Only for the reason that he is too old to run away but too young to move out did he stop and wait.

From the first run-away act to the last one, Jules proves to be excessively vulnerable in confrontation with the compulsive environment. The feeling of alienation, as a result of the restrictive environment, is the primary motive to force the child to shake off the bondages imposed by the external world. In Oates's description, two facts that are concerned with fire make the matters worse and result in his spiritual dilemma.

One event is around something spectacular-a two-passenger plane crashes. They go over there and stare. "The air was vibrating in spasms from the heat. It looked as if it were shivering, in violent anticipation of seeing something awful” (Oates, 1969, p. 70). Loretta feels shocked:

So this was what those photographs of burning plane were all about-the billowing, gulping noise of a gasoline and oil fire, a queer sound that put her in mind of sheets flapping on a clothesline. Weeds caught on fire and shriveled in a second, flame illuminating their dark kernels and then blinding them and, in another second, wasting them away to nothing. (Oates, 1969, p. 71)

His only fascination is running away. When he realizes the deathly outcome, he sets himself apart from other people and indulge himself in absolute panic.

It was frightening that he should sit like that, so still. She could hear him saying something, talking to himself. A rapid, frightened mumble... a kind of breathy argument... He was hiding from them. He was hiding from them and talking to himself, arguing out something. He seemed both angry and scared...She leaned against the rotted doorway and felt a giddiness rise in her, cut off from Jules by his aloneness, his being so unchildlike. (Oates, 1969, p. 72)

Loretta feels shocked by her son's gesture and just freezes. In the initial period of Jules's life, the traditional authority like family fails to guide Jules out of spiritually felt danger. Ever since then, he is involved in a margined state of life.

The other event happens in one of the barns when he is playing there. Since Jules is always a daring child, frightened of nothing. In demonstrating magic to his sister, he sets the barn on fire. On the moment of lighting a match, "It seemed to him that the flame of the match belonged to him, that it had something to do with the words he had uttered" (Oates, 1969, p. 76). A pile of hay catch fire and the scene reminds him of the other fire he had seen, and "the other big fire, was the airplane fire, and that had been boiling and vicious, flames rising as high as a house, out of control... Hayseeds and dust on a rafter caught fire in a quick liquid-like spreading, running up toward the cobwebbed roof like lightning in reverse, striking Jules with its beauty” (Oates, 1969, p. 77). It seems that Jules is labelled by his "bad" deed announced by Maureen. On the contrary, when the fire spreads into several directions, he appreciates its beauty. When excitement is over, he comes out to receive a brutal whipping from his grandmother and is predicted by his grandma that someday he will die in the electric chair. Being unable to live up to his ideal of freedom, Jules gradually develops a sense of defeat. 
Since he is just a child, people would always view his action as naughty behavior. Nonetheless, we can obviously find his natural desire for self-identity, freedom and also the puzzlement that he can not understand as young as he is. The vulnerability turns out to be a universal human condition and powerfully presented in Jules's response to this event. The significance lies in the fact that his experience in boyhood impresses him so much that it will reappear in the future in various ways.

\section{Flight to the Urban City}

Unwilling to waste her youth and energy on the barren, rural landscape, and the imperious Ma Wendall, Loretta flees to the city of Detroit with her children. Poverty seems to haunt them from the countryside to Detroit where Loretta is arrested for prostitution on her second day in the city. After World War II, the entire family is reunited and bound together by poverty in the slums of Detroit. To make things worse, Howard is killed in an industrial accident. Loretta is left alone to care for their three children and her mother-in-law by herself. Poverty not only victimizes Loretta but also set the tone for her children's lives.

Most of Oates' fiction is the exploration of the contemporary world interpreted in a realistic mode, which might be called a tragic viewpoint. She says:

Most of my writing is preoccupied with the imagination of pain, and this is simply because people need help with pain, never with joy. There's no need to write about happy people, happy problems; there's only the moral need to instruct readers concerning the direction to take, in order to achieve happiness (or whatever: maybe they don't want happiness, only confusion). So I feel the moral imperative to chart the psychological processes of someone, usually a hero, but sometimes a heroine, who has gone through suffering of one kind or another, but who survives it (or almost survives). (Oates, 1972, p. 136)

Although his heart anguishes within him when he learns that nobody really concerns him, he still feels optimistic about freedom.

He had no belief in God, no interest. He pressed his fingertips against his eyeballs and tried to imagine, deep in the interior of his own brain, a being not quite himself who watched him, angry and hateful and loving of him, but he could not imagine it, not really; who beside Jules could love or hate Jules? When he turned quickly on the street it was usually to see no one-nothing. There was nothing behind him. Nothing followed him. At night, when he woke suddenly, there was nothing close to him, breathing over him, watching. He was only himself, free. (Oates, 1969, p. 94)

Enjoying his solitude, he lingers in the dark alleys that help him achieve temporary freedom and revelation. He pauses at the end of an alley, and "by himself he was light as air, with all possibilities open before him, just as they were open to the enviable heroes of books and movies. On his own, now, he was entirely on his own. The block was a block of commercial buildings, all dark” (Oates, 1969, p. 122). The cold fact shows that there is no reconciliation between his individuality and the impoverished environment. However, Jules still holds hope for his fantastic future until the failure of his love with Nadine, Jules starts to realize the cruelness of reality.

\section{Conclusions}

This paper focuses on Oates' novel them, in which the protagonist Jules is characterized as a young man who is obsessed with the idealized world in his life which is first and foremost symbolized as a distant place. Frustrated by the attempts to run away from the rural area more than once, he chooses to distance himself from the others in a gesture of an encaged animal. Moving to the city, he proceeds to construct his idealized world that takes the form 
of a variety of romantic affairs and wealth adventures. Right deep in his heart, he wants to be loved but fails; he wants to love others, but he fails once again. The reason lies in the fact that his behavior has already deviated from the normal one. In consequence, both his lovers and the donors make a false representation with an evil intent to cause injury to him. Gradually, he is deprived of his previous ambition and innocent view of the world.

Jules is not aware of the pain described by Oates. He does his own part as the eldest son of the family. He works for 50 cents an hour as a part time job in a parking lot. Sometimes when he helps a man who has had too much to drink, he feels keenly the gap in between that "they were not walking together, not really. The tips of a dollar or more he sometimes got were a sign of this difference and that it existed powerfully and irreparably" (Oates, 1969, p. 120). It is the social environment that guides Jules to pursue wealth as the token of success. However, he cannot limit himself to the control of money. As for him, money is the means by which he could fulfill his ambition of being a character in a book. Then he may carry out his arrangement with his family and his own future. First he would buoy up his family and slide out from under them. And then he will float out and away upon the ocean of America, all the way across the Midwestern prairies and the Rockies to the West Coast. Jules holds a romantic dream of fleeing to the golden West. "He thought of a wilderness, land out West; a golden sky, or perhaps a golden field of wheat... mountains... rivers... something unmapped” (Oates, 1969, p. 102). The fantasies reveal his intention of escaping from destruction. Through the imagination of a future self, Jules seeks liberation that will triumph over the present chaotic condition. This is an ambitious plan in fantasy, which represents his intention of fleeing from the past. With a deep trust in himself, he longs for something better. His identity is not only dependent upon himself, but also upon the external objects which he uses to measure himself. Similarly, while wandering on those dark alleys, his sense of loss becomes rendered again.

\section{References}

Baym, N. (Ed.). (1989). The Norton anthology of American literature. New York: W.W. North \& Company.

Bettelheim, B. (1977). The uses of enchantment: The meaning and importance of fairy tales. New York: Knopf.

Breachler, L., \& Walter Litz, A. (Eds.). (1991). Modern American women writers. New York: Simon and Schuster Macmillan.

Chodorow, N. (1978). The reproduction of mothering: Psychoanalysis and the sociology of gender. Los Angeles: University of California Press.

Creighton, J. V. (1979). Critical essays on Joyce Carol Oates. Boston: G.K. Hall.

DeCurtis, A. (1979). The process of fictionalization in Joyce Carol Oates’s them. International Fiction Review, 6.

Fossum, R. H. (1979). Only control: The novels of Joyce Carol Oates. Boston: G.K. Hall \& C..

Franks, L. (Ed.). (1989). Conversations with Joyce Carol Oates. L. Milazzo (Ed.). Mississippi: University Press of Mississippi.

French, R. M. (1969). The community: A comparative perspective. Los Angeles: F.E. Peacock.

Freud, S. (1974). The resistance to psycho-analysis. London: The Hogarth Press.

Freud, S. (2006). A general introduction to psychoanalysis. Xi'an: Shanxi People’s Publishing House.

Friedman, G. E. (1980). Joyce Carol Oates. New York: Frederich Ungar Publishing Co..

Johnson, G. (2006). Understanding Joyce Carol Oates. Princeton: Ontario Review Press.

Oates, J. C. (1969). them. New York: The Vanguard Press.

Oates, J. C. (1971). An American tragedy. New York Book Review, 24.

Oates, J. C. (1972). The edge of impossibility: Tragic forms in literature. New York: the Vanguard press. 